Article

\title{
Inhibitory Effect of Depolymerized Sulfated Galactans from Marine Red Algae on the Growth and Adhesion of Diarrheagenic Escherichia coli
}

\author{
Yixiang Liu ${ }^{1,2, *} \mathbb{1}$, Wenqiang Liu ${ }^{1}$, Yanbo Wang ${ }^{3}$, Yu Ma ${ }^{1}$, Ling Huang ${ }^{1}$, Chao Zou ${ }^{1}$, \\ Donghui Li ${ }^{1}$, Min-Jie Cao ${ }^{1}$ and Guang-Ming Liu ${ }^{1,2}$ \\ 1 College of Food and Biological Engineering, Jimei University, Xiamen 361021, China; \\ lwq19950512@163.com (W.L.); my358108@163.com (Y.M.); 15574291255@163.com (L.H.); \\ zouchaoknight@163.com (C.Z.); dh15589515872@163.com (D.L.); mjcao@jmu.edu.cn (M.-J.C.); \\ gmliu@jmu.edu.cn (G.-M.L.) \\ 2 Xiamen Key Laboratory of Marine Functional Food, Xiamen 361021, China \\ 3 School of Food Science and Biotechnology, Zhejiang Gongshang University, Hangzhou 310018, China; \\ wangyb@mail.zjgsu.edu.cn \\ * Correspondence: lyxjmu@jmu.edu.cn; Tel.: +86-0592-6181915; Fax: +86-0592-6180470
}

Received: 3 November 2019; Accepted: 7 December 2019; Published: 10 December 2019

check for updates

\begin{abstract}
Active polysaccharides as safe and natural polymers against bacterial diarrhea have been reconsidered as an alternative to antibiotics. This work investigated the inhibiting effect of depolymerized sulfated galactans from Eucheuma serra and Gracilaria verrucosa on the growth and adhesion of diarrheagenic enterotoxigenic Escherichia coli (ETEC) K88. Results showed that the sulfated polysaccharides with molecular weight distribution $\leq 20.0 \mathrm{kDa}$ exhibited antibacterial activity against ETEC K88. A structure-activity study revealed that the anti-ETEC K88 activity of sulfated polysaccharides is strictly determined by their molecular weight distribution, sulfate group content, and monosaccharide composition. In addition, the promoted nucleic acid release and the fluorescence quenching of membrane proteins were observed after the treatment with selected polysaccharides. Scanning electron microscopy further confirmed that the depolymerized sulfated galactans can effectively inhibit ETEC K88 adhesion. In conclusion, depolymerized sulfated galactans exhibited an inhibitory effect on the growth and adhesion of ETEC K88.
\end{abstract}

Keywords: sulfated galactans; marine algae; enterotoxigenic Escherichia coli; anti-diarrhea; anti-adhesion

\section{Introduction}

Morbidity and mortality from human intestinal pathogens, including diarrheagenic Escherichia coli (E. coli), has become an enormous global burden [1]. Diarrheagenic bacteria can enter the gastrointestinal digestive system through food, adhere to and infect gastrointestinal epidermal cells, and thus cause vomiting, diarrhea, and even intestinal bleeding [2]. Various antibiotics have been widely used in the treatment of diarrhea, and the curative effect is definite. However, the use of these drugs can damage the growth of intestinal probiotics [3]. In addition, owing to the long-term use of antibiotics, genetic mutations and selective pressure have pushed enteric pathogenic bacteria to become resistant or multi-resistant to antibiotics [3]. Therefore, the development of novel compounds as alternative therapies or preventive agents has become increasingly important.

As the main bioactive components in marine algae, sulfated polysaccharides, particularly their bacteriostatic or bactericidal activity, have attracted attention [4]. In brown algae, the sulfated polysaccharides from Laminaria japonica and Sargassum swartzii can inhibit Gram-negative and -positive 
bacteria including E. coli, Vibrio cholera, Salmonella typhi, and Staphylococcus aureus [5,6]. The sulfated polysaccharides from green algae (Chaetomorpha aerea) and microalgae (Porphyridium cruentum) also display inhibitory effect on $S$. aureus and Salmonella enteritidis, respectively $[7,8]$. For red algae, the sulfated polysaccharide from Hypnea musciformis can effectively inhibit diarrhea in rodents [9].

As the traditional edible red seaweed in China, Eucheuma serra and Gracilari verrucosa have become the main raw materials for the production of carrageenan and agar, respectively [10]. Compared with those from other algae, the sulfated polysaccharide from red algae is more homogeneous in sugar composition. These polysaccharides usually have about $90 \%$ of linear backbone built up of alternating 3 -linked $\beta$-D-galactopyranose and 4 -linked $\alpha$-D-galactopyranose residues [11]. The hydroxyl groups of galactose residues in side chains may be substituted by ester sulfate and methyl groups [12]. Therefore, the major sulfated polysaccharides in red algae are generally in the form of sulfated galactans [13]. A recent study showed that the sulfated galactans from Gracilaria ornate exhibit antibacterial activity against only E. coli among two Gram-positive and five Gram-negative bacteria [14].

As Gram-negative bacteria, enterotoxigenic E. coli (ETEC) K88 is a worldwide cause of severe diarrhea in humans and animals [1]. In this study, two kinds of sulfated galactans were extracted from E. serra and G. verrucosa. The inhibitory effect of sulfated galactans on the growth of diarrheagenic ETEC K88 was investigated. In addition, the anti-adhesive property of sulfated galactans against ETEC K88 was discussed. This work is important in utilizing red algae to produce natural antibacterial polysaccharides.

\section{Results}

\subsection{Yield and Composition of Polysaccharides}

Sulfated polysaccharides were obtained through hot water extraction and ethanol precipitation. The yields of crude sulfated galactans extracted from E. serra and G. verrucosa were $19.5 \%(\mathrm{w} / \mathrm{w})$ and $7.6 \%(\mathrm{w} / \mathrm{w})$, respectively. The chemical compositions of the sulfated galactans are summarized in Table 1. E. serra sulfated polysaccharide (ESP) was composed of total carbohydrate $78.3 \%$, sulfate 28.2\%, 3,6-anhydrogalactose (3,6-AG) 9.8\%, and uronic acid 2.2\%. For its monosaccharide composition, galactose $(93.4 \%)$ was the major component, and small amounts of glucose $(0.6 \%)$, glucuronic acid $(0.9 \%)$, galacturonic acid $(0.9 \%)$, xylose $(1.1 \%)$, and mannose $(3.2 \%)$ were also found. G. verrucosa sulfated polysaccharide (GSP) has the similar monosaccharide composition except for the xylose content. The GSP was composed of total carbohydrate $83.8 \%$, sulfate $13.1 \%$, 3,6-AG $13.4 \%$, and uronic acid $4.2 \%$. ESP and GSP have mixed sugars, and their monosaccharide units are mainly galactose; however, ESP has higher sulfate content but lower uronic acid and 3,6-AG content than GSP.

Table 1. Yield and chemical composition of crude polysaccharide from red seaweeds.

\begin{tabular}{|c|c|c|c|}
\hline \multicolumn{2}{|l|}{ Items } & $\mathrm{ESP}^{\mathrm{a}}$ & GSP $^{b}$ \\
\hline \multicolumn{2}{|c|}{ Yield $(\%, w / w)^{c}$} & $19.5 \pm 1.2$ & $7.6 \pm 0.5$ \\
\hline \multicolumn{2}{|c|}{ Sulfate $(\%, w / w)$} & $28.2 \pm 2.1$ & $13.1 \pm 1.9$ \\
\hline \multicolumn{2}{|c|}{ Total carbohydrate $(\%, \mathrm{w} / \mathrm{w})$} & $78.3 \pm 4.5$ & $83.8 \pm 3.1$ \\
\hline \multicolumn{2}{|c|}{ Uronic acid $(\%, \mathrm{w} / \mathrm{w})$} & $2.2 \pm 0.3$ & $4.2 \pm 0.4$ \\
\hline \multicolumn{2}{|c|}{ 3,6-anhydrogalactose $(\%, \mathrm{w} / \mathrm{w})$} & $9.8 \pm 0.3$ & $13.4 \pm 0.5$ \\
\hline \multirow{6}{*}{ Monosaccharide composition (\%) $d$} & Mannose & 3.2 & 2.7 \\
\hline & Glucuronic acid & 0.9 & 0.4 \\
\hline & Galacturonic acid & 0.9 & 1.2 \\
\hline & Glucose & 0.6 & 2.2 \\
\hline & Galactose & 93.4 & 93.5 \\
\hline & Xylose & 1.1 & 0 \\
\hline
\end{tabular}

\footnotetext{
a Sulfated polysaccharide extracted from Eucheuma serra. ${ }^{\text {b }}$ Sulfate polysaccharide extracted from Gracilaria verrucosa

c Calculated according to the dry weight of algae. ${ }^{\mathrm{d}}$ Calculated according to the peak area ratio of the detected monosaccharides in liquid chromatogram.
} 


\subsection{Effect of Depolymerization on the Antibacterial Activity of Sulfated Galactans}

After being hydrolyzed by high temperature and pressure, ESP and GSP had significantly decreased intrinsic viscosity $(p<0.01)$ and increased content of reducing sugar $(p<0.01)$ (Figure 1a,b). The sulfate contents of ESP and GSP were $28.2 \%$ and $13.1 \%$, respectively, but no significant $(p<0.05)$ changes were observed in their depolymerized products (Figure 1c). The results of FT-IR spectrum analysis are shown in Figure 1d-1,2. The sulfated polysaccharides before and after depolymerization shared the similar spectral feature. ESP and GSP and their corresponding depolymerized products exhibited absorption peaks at 3438,2935 , and $1064 \mathrm{~cm}^{-1}$, which are characteristic absorptions of -OH, $\mathrm{C}-\mathrm{H}$, and C-O, respectively [15]. The peak at $933 \mathrm{~cm}^{-1}$ can be attributed to 3,6-AG (C-O-S) [16]. The most important peaks for ESP and GSP and their depolymerized products are located at approximately 1244 and $1265 \mathrm{~cm}^{-1}$, respectively, which correspond to the stretching vibration of the ester sulfate groups $(\mathrm{S}=\mathrm{O})[6,17]$. Considering the stronger sulfated group peak in ESP spectra than that in GSP, the former was more sulfated than the latter. This result is consistent with those in Table 1. The effect of depolymerization on the antibacterial activity of sulfated galactans is shown in Figure 1e-1-6. Compared with the depolymerized polysaccharides, the unprocessed ones did not show antibacterial activity against ETEC K88. However, the growth of ETEC K88 was inhibited on the culture plates for D-ESP and D-GSP at $7.5 \mathrm{mg} / \mathrm{mL}$.

\subsection{Effect of Molecular Weight on Antibacterial Activity}

D-ESP and D-GSP were divided into different fractions by using ultrafiltration membranes with different molecular interceptions to clarify the molecular weight distribution of the depolymerized sulfated galactans that can effectively inhibit diarrhea-causing ETEC K88. As shown in Figure 2, the $\leq 20 \mathrm{kDa}$ fractions in D-ESP and D-GSP displayed varying degrees of antibacterial activity against ETEC K88 in a dose-dependent manner ranging from $6.0 \mathrm{mg} / \mathrm{mL}$ to $10.0 \mathrm{mg} / \mathrm{mL}$. For D-ESP and D-GSP, the antibacterial activity of the $\leq 6 \mathrm{kDa}$ fraction was better than that of the $6-20 \mathrm{kDa}$ fraction. However, when the molecular weight of the sulfated galactans was $>20 \mathrm{kDa}$, no antibacterial activity was observed. According to the results in Table 2, the minimal inhibitory concentration (MIC) values of $6-20 \mathrm{kDa}$ and $\leq 6 \mathrm{kDa}$ fractions in D-ESP were also lower than that of the corresponding two fractions in D-GSP. These data indicated that $\leq 20 \mathrm{kDa}$ sulfated galactans can effectively inhibit ETEC K88 growth. As shown in Table 2, the active products account for 66.7\% in D-ESP and 55.7\% in D-GSP.

According to ours and other previous studies, sulfate groups of marine polysaccharides are closely related with their biological activity, such as antibacterial and anti-tumor activities $[3,6]$. The content of sulfate groups should be another important factor for the inhibiting effect of sulfated galactans on ETEC K88. Compared with those of D-GSP, the $\leq 6 \mathrm{kDa}$ and $6-20 \mathrm{kDa}$ fractions of D-ESP exhibited higher inhibiting activity for ETEC K88 growth (Figure 2). As shown in Table 2, the sulfate group content was $27.2 \%$ and $31.4 \%$ for the $\leq 6 \mathrm{kDa}$ and $6-20 \mathrm{kDa}$ fractions in D-ESP, respectively, but was only about $12 \%$ for the two corresponding fractions in D-GSP. It is indicated that there may be a correlation between sulfate group content and antibacteral activity for sulfated galactans against ETEC K88. In the following experiments, the influence of anionic properties on the anti-ETEC K88 activity of depolymerized sulfated galactans was further discussed. 

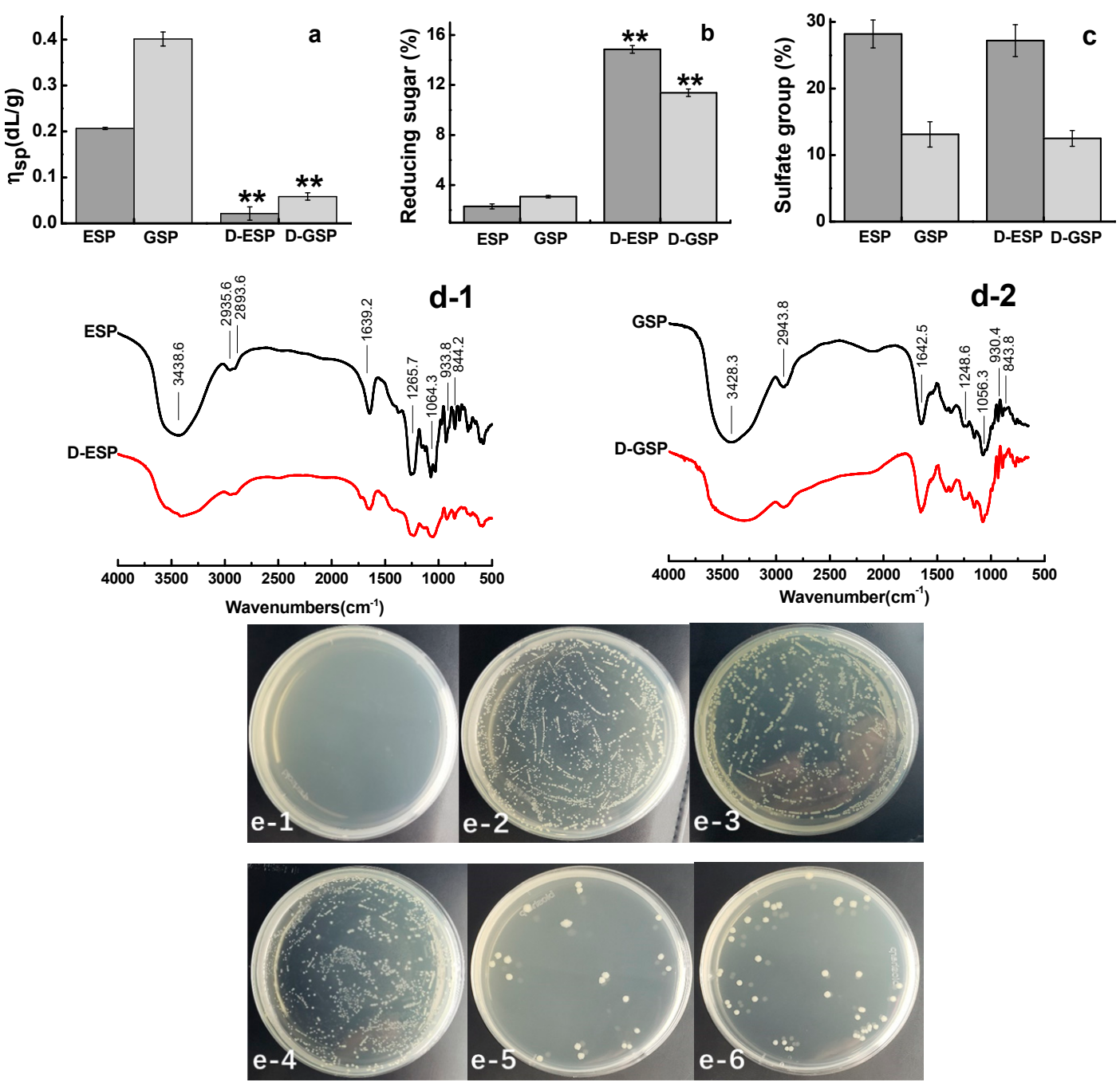

Figure 1. Effect of depolymerization on the antibacterial activity of sulfated galactans. (a) Viscosity, (b) reducing sugar, (c) sulfate group, (d) FT-IR analysis of E. serra sulfated polysaccharide (ESP) and depolymerized ESP (D-ESP) (d-1) and G. verrucosa sulfated polysaccharide (GSP) and depolymerized GSP (D-GSP) (d-2), and (e) antibacterial activity of sulfated galactans against enterotoxigenic E. coli (ETEC) K88: (e-1) positive control ( $0.05 \mathrm{mg} / \mathrm{mL}$ kanamycin), (e-2) negative control ( $0.85 \% \mathrm{NaCl}$ saline), (e-3) $7.5 \mathrm{mg} / \mathrm{mL}$ ESP, (e-4) $7.5 \mathrm{mg} / \mathrm{mL}$ GSP, (e-5) $7.5 \mathrm{mg} / \mathrm{mL}$ D-ESP, and (e-6) $7.5 \mathrm{mg} / \mathrm{mL}$ D-GSP.
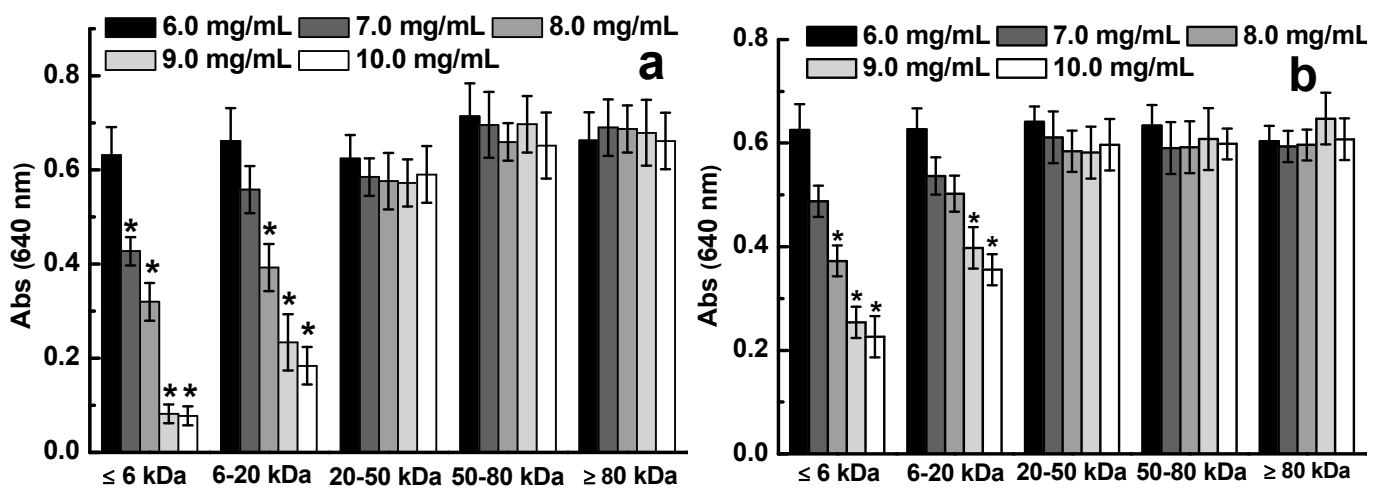

Figure 2. Effect of molecular weight on the antibacterial activity of D-ESP (a) and D-GSP (b). 
Table 2. Yields and sulfate group contents of different fractions of D-ESP and D-GSP.

\begin{tabular}{ccccccc}
\hline \multirow{2}{*}{ Fractions } & \multicolumn{3}{c}{ D-ESP } & \multicolumn{3}{c}{ D-GSP } \\
\cline { 2 - 7 } & Yield (\%) & $\begin{array}{c}\text { Sulfate } \\
\text { Group (\%) }\end{array}$ & $\begin{array}{c}\text { MIC } \\
(\mathbf{m g} / \mathbf{m L})\end{array}$ & Yield (\%) & $\begin{array}{c}\text { Sulfate } \\
\text { Group (\%) }\end{array}$ & $\begin{array}{c}\text { MIC } \\
(\mathbf{m g} / \mathbf{m L})\end{array}$ \\
\hline Mixure & 100.0 & $28.3 \pm 1.9$ & 25.0 & 100.0 & $13.3 \pm 1.7$ & 40.0 \\
$\leq 6 \mathrm{kDa}$ & 43.2 & $27.2 \pm 2.4$ & 15.0 & 22.6 & $12.5 \pm 1.2$ & 25.0 \\
$6-20 \mathrm{kDa}$ & 23.5 & $31.4 \pm 3.4$ & 20.0 & 33.1 & $12.1 \pm 2.1$ & 30.0 \\
$20-50 \mathrm{kDa}$ & 16.9 & $29.7 \pm 2.6$ & - & 7.5 & $10.5 \pm 2.3$ & - \\
$50-80 \mathrm{kDa}$ & 9.3 & $31.4 \pm 3.2$ & - & 9.3 & $12.4 \pm 2.4$ & - \\
$>80 \mathrm{kDa}$ & 7.1 & $24.9 \pm 1.9$ & - & 27.5 & $11.6 \pm 1.1$ & - \\
\hline \multicolumn{7}{c}{}
\end{tabular}

\subsection{Effect of Anionic Properties on Antibacterial Activity}

The $\leq 6 \mathrm{kDa}$ D-ESP and D-GSP were further separated into different fractions by using an anion exchange chromatograph to illustrate the effect of polyanionic property on the anti-ETEC K88 activity of depolymerized sulfated galactans. As shown in Figure 3a,b, three fractions E1, E2, and E3 were obtained from D-ESP by sequentially eluting it with $0,0.1$, and $0.5 \mathrm{~mol} / \mathrm{L} \mathrm{NaCl}$. For D-GSP, G1 and $\mathrm{G} 2$ fractions were eluted by 0.3 and $0.5 \mathrm{~mol} / \mathrm{L} \mathrm{NaCl}$, respectively. Table 3 shows the MIC and minimal bactericidal concentration $(\mathrm{MBC})$ values of different polysaccharide fractions with different sulfate group and uronic acid contents in the sugar chain. Owing to the low uronic acid content, the sulfate group may be the main factor contributing to the polyanionic characteristics of the investigated polysaccharides. However, this hypothesis needs further verification. As shown in Table 3, the E3 fraction with $8.0 \mathrm{mg} / \mathrm{mL}$ MIC and $12.5 \mathrm{mg} / \mathrm{mL}$ MBC displayed better anti-ETEC K88 activity and had higher sulfate group content compared with other fractions.
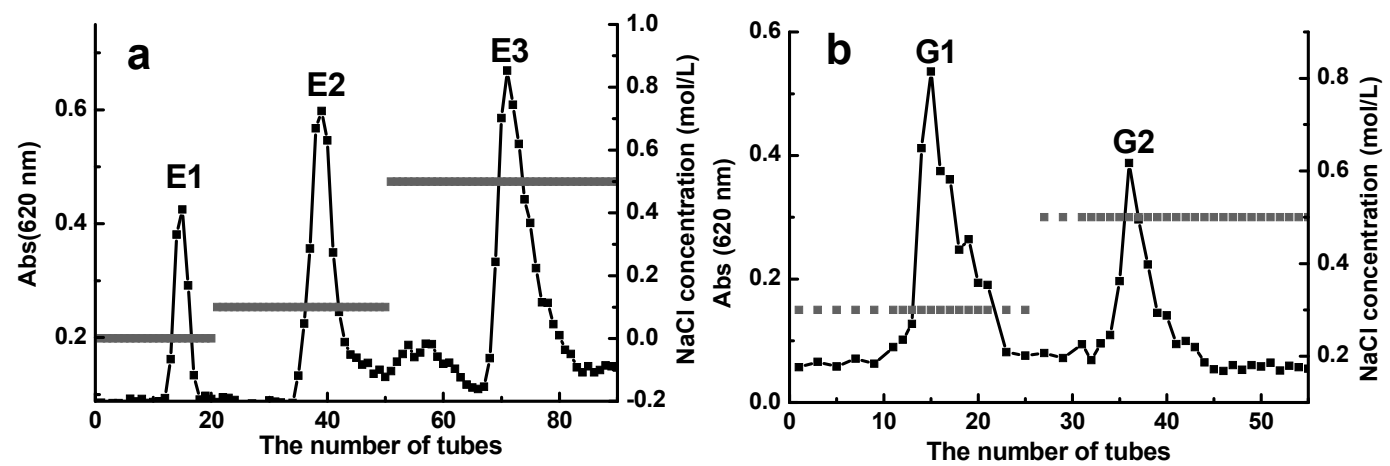

Figure 3. Separation of $<6 \mathrm{kDa}$ D-ESP (a) and D-GSP $(\mathbf{b})$ by diethylaminoethyl (DEAE)-cellulose 52 anion exchange chromatography and comparative analysis of their antibacterial activity against ETEC-K88.

Table 3. Antibacterial activity of sulfate polysaccharides with different anionic properties.

\begin{tabular}{cccccc}
\hline \multirow{2}{*}{ Test Items } & \multicolumn{3}{c}{ D-ESP } & \multicolumn{3}{c}{ D-GSP } \\
\cline { 2 - 6 } & E1 & E2 & E3 & G1 & G2 \\
\hline MIC $(\mathrm{mg} / \mathrm{mL})$ & 10.0 & 10.0 & 8.0 & 12.5 & 10.0 \\
MBC $(\mathrm{mg} / \mathrm{mL})$ & 25 & 25 & 12.5 & 25.0 & 25.0 \\
Sulfate group $(\%, \mathrm{w} / \mathrm{w})$ & $19.4 \pm 2.8$ & $23.8 \pm 3.1$ & $29.2 \pm 2.2$ & $16.9 \pm 2.1$ & $23.1 \pm 1.4$ \\
Uronic acid $(\%, \mathrm{w} / \mathrm{w})$ & $0.7 \pm 0.1$ & $1.2 \pm 0.1$ & $1.6 \pm 0.1$ & $2.2 \pm 0.2$ & $2.9 \pm 0.2$ \\
\hline
\end{tabular}

\subsection{Effect of Monosaccharide Composition on Antibacterial Activity}

To reveal the effect of monosaccharide composition on the anti-ETEC K88 activity of sulfated galactans, D-ESP, fucoidan, and dextran sulfate were selected in this work. These polysaccharides have similar sulfate content $(23.8 \%, 23.1 \%$, and $20.0 \%$ for D-ESP, fucoidan, and dextran sulfate, respectively) 
and molecular weight distribution ( $\leq 6 \mathrm{kDa}$ for D-ESP and fucoidan and $5 \mathrm{kDa}$ for dextran sulfate) but different monosaccharide composition. Figure $4 \mathrm{a}-\mathrm{c}$ show the anti-ETEC K88 activity of these three polysaccharides. Compared with D-ESP, fucodian ranging from $4.0 \mathrm{mg} / \mathrm{mL}$ to $8.0 \mathrm{mg} / \mathrm{mL}$ displayed better inhibitory effect on ETEC K88 growth. These results were confirmed by the MIC values, in which the $\leq 6 \mathrm{kDa}$ fractions for D-ESP and fucoidan were 15.0 and $12.5 \mathrm{mg} / \mathrm{mL}$, respectively. However, no anti-ETEC K88 activity was observed for dextran sulfate even at $10.0 \mathrm{mg} / \mathrm{mL}$. Therefore, how monosaccharide composition affects the antibacterial function of polysaccharides remains to be further studied.
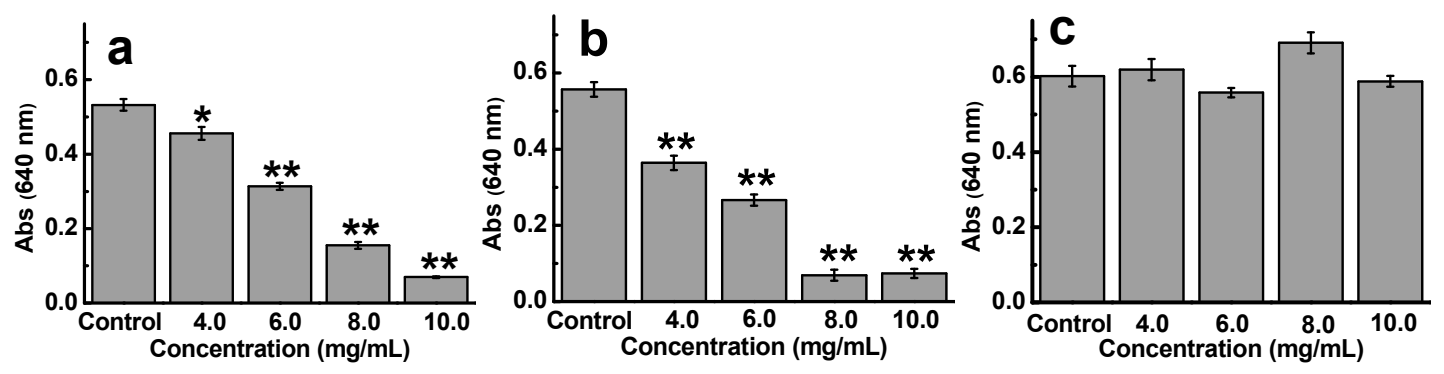

Figure 4. Effect of monosaccharide composition on the anti-ETEC K88 activity of sulfated polysaccharides. (a-c) are D-ESP ( $\leq 6 \mathrm{kDa}, 23.8 \%$ sulfate), fucoidans from Laminaria japonica ( $\leq 6 \mathrm{kDa}$, $23.1 \%$ sulfate), and standard dextran sulfate ( $5 \mathrm{kDa}, 20 \%$ sulfate), respectively.

\subsection{Effect of Sulfated Galactans on Cell Membrane Integrity}

As shown in Figure 5, the absorbance of the suspensions of ETEC K88 at $260 \mathrm{~nm}$ significantly increased with time after the bacteria were treated with the E3 fraction of D-ESP and the G2 fraction of D-GSP at their MBC concentrations $(p<0.01)$. After $5 \mathrm{~h}$, maximum absorption was reached for both fractions. From $5 \mathrm{~h}$ to $11 \mathrm{~h}$, the nucleic acid release of ETEC-K88 treated with E3 fraction was significantly higher than that of ETEC K88 treated with G2 fraction $(p<0.05)$. This result indicates that the E3 fraction is more destructive to bacterial cell membrane than the G2 fraction.
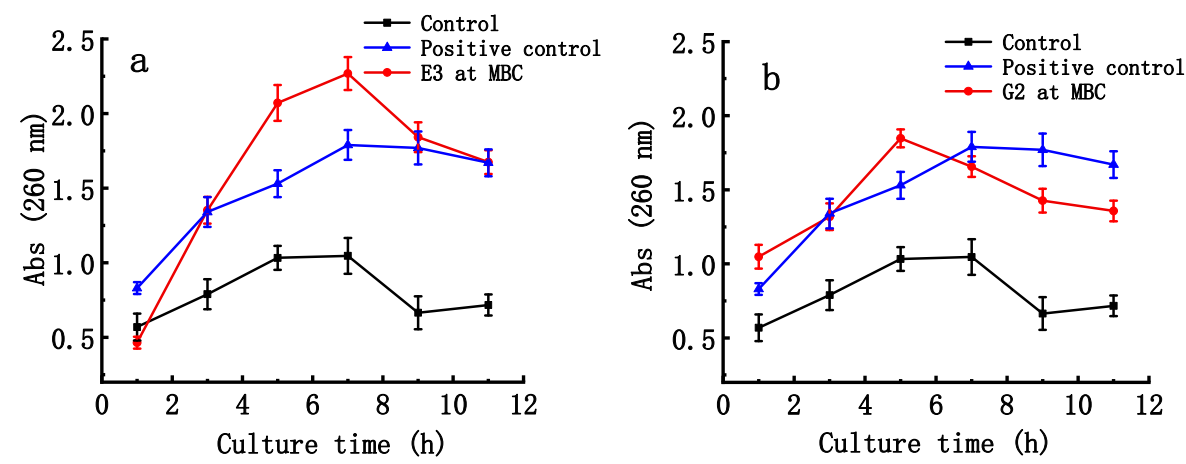

Figure 5. Effect of depolymerized sulfated galactans on nucleic acid releases in bacterial suspension at the minimal bactericidal concentration (MBC). (a,b) show nucleic release in time pattern after ETEC K88 samples were treated with the E3 fraction of D-ESP and G2 fraction of D-GSP, respectively. Positive control is kanamycin $(0.05 \mathrm{mg} / \mathrm{mL})$.

\subsection{Effect of Sulfated Galactans on Cell Membrane Proteins}

Attributing to the residues, including tryptophan, tyrosine, and phenylalanine, proteins usually can exhibit fluorescence property [6]. Therefore, if the membrane proteins of bacteria were combined with sulfated polysaccharides, their fluorescence properties should be suppressed [6]. The changes of membrane proteins were investigated to reveal the antibacterial mechanisms of sulfated galactans against ETEC-K88. Figure 6a,b shows that after ETEC K88 was exposed to E3 and G2 fractions for $4 \mathrm{~h}$, a dose-dependent decrease in fluorescence intensity was observed. When the concentration of sulfated 
galactans was increased to $6.0 \mathrm{mg} / \mathrm{mL}$, the maximal fluorescence intensity decreased from 1000 to 480 and 710 for E3 and G2 fractions, respectively. This result implied that the E3 fraction was more easily bound to the cell surface of ETEC-K88 than the G2 fraction. A red shift of the maximum emission wavelength was also observed. In addition, after being administered with the E3 and G2 fractions under the MBC concentrations for $5 \mathrm{~h}$, the morphological and physical changes of treated bacteria were observed by SEM (Figure 6c-e). These images suggested that the depolymerized sulfated galactans might destroy the surface of the tested bacteria. The surfaces of the treated ETEC K88 underwent obvious morphological changes compared with the untreated control. Untreated cells were regular, intact, and with smooth surfaces (Figure 6c), whereas the bacterial cells treated with the E3 and G2 fractions became deformed, pitted, and shriveled (Figure 6d,e).
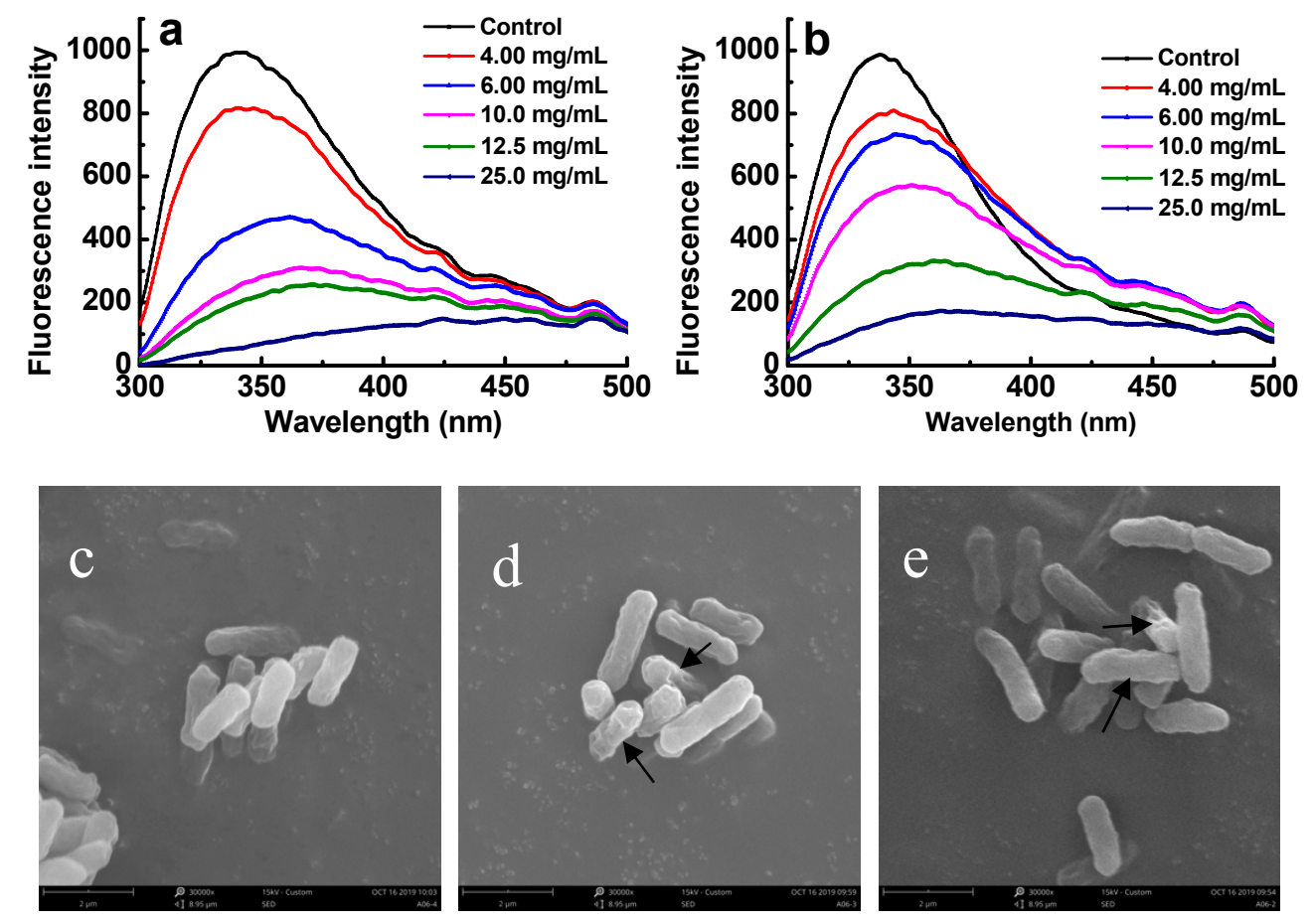

Figure 6. Effect of sulfated galactans on cell membrane of ETEC K88. (a,b) show fluorescence intensity changes of bacterial suspensions exposed to the E3 fraction of D-ESP and G2 fraction of D-GSP for $5 \mathrm{~h}$. (c-e) respectively show the SEM images of ETEC K88 without and with E3 and G2 treatment under their $\mathrm{MBC}$ concentrations for $5 \mathrm{~h}$.

\subsection{Effect of Sulfated Galactans on Bacterial Adhesion}

When S. cerevisiae or ETEC K88 was exposed to $6.0 \mathrm{mg} / \mathrm{mL}$ of E3 or G2 fraction for $4 \mathrm{~h}$, no obvious changes of microbial viability were observed. Therefore, under these conditions, the effect of sulfated galactans on bacterial adhesion was investigated. Figure $7 \mathrm{a}$ shows that after $4 \mathrm{~h}$ of co-incubation, a certain number of ETEC K88 accumulated around the cell wall of S. cerevisiae. However, the aggregation state of S. cerevisiae and ETEC K88 was ameliorated when E3 and G2 fractions were added to the culture system at $6.0 \mathrm{mg} / \mathrm{mL}$. According to the SEM observations in Figure 7b,c, ETEC K88 did not adhere on the cell wall of $S$. cerevisiae after the treatment of depolymerized sulfated galactans. 


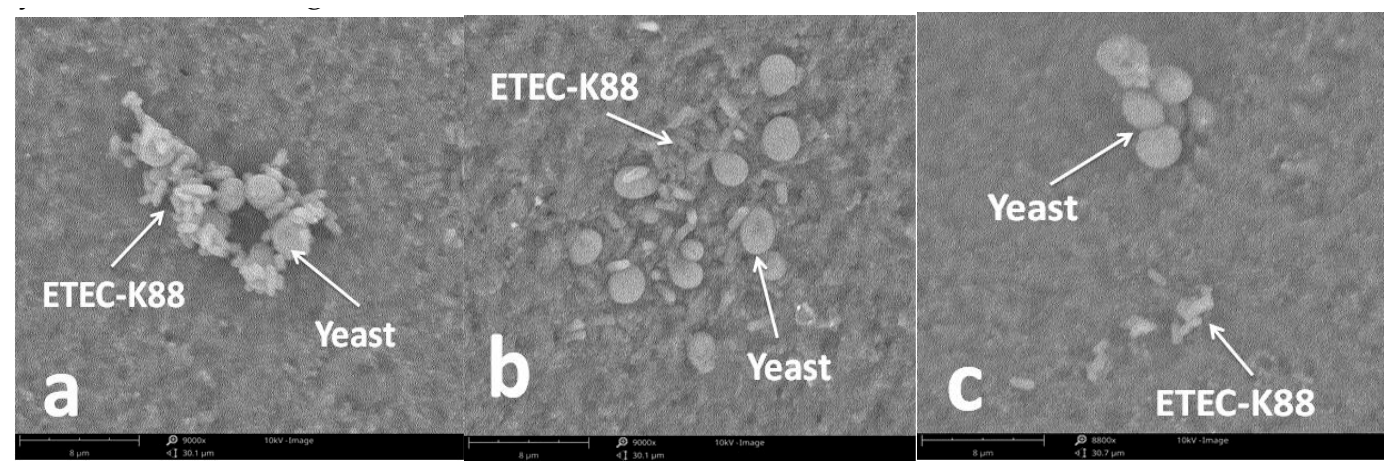

Figure 7. Effect of sulfated galactans on the adhesion of ETEC K88 on the surface of yeast cells observed by SEM after $4 \mathrm{~h}$ treatment. (a) is control (no sulfated galactans), and (b,c) represent E3 and G2 fractions both at $6.0 \mathrm{mg} / \mathrm{mL}$, respectively.

\section{Discussion}

In this work, two kinds of sulfated galactans were extracted from E. serra and G. verrucosa. Although their monosaccharide units are mainly galactose, they differ in sulfate content, uronic acid, and 3,6-AG content. Several factors, including environmental conditions, seasonal variation, physiological factors, and extraction methods contribute to the variation in sulfated galactan yield from red seaweeds [18]. The chemical and structural properties of sulfated galactans in red algae vary within species. Even in the same species, the polysaccharide showed structural differences depending on life cycle stage and geographical location [9]. For example, the sulfated galactans extracted from the red seaweed Mastocarpus stellatus are composed of $95.2 \%$ galactose and minor amounts of xylose $(2.5 \%)$ and glucose (2.4\%) [18], whereas those from Gracilaria genus are composed mainly of alternating D-galactose and L-galactose [11].

Interestingly, only depolymerized sulfated galactans displayed anti-ETEC K88 activity according to our present results. For D-ESP and D-GSP, the antibacterial activity of the $\leq 6 \mathrm{kDa}$ fraction was better than that of the $6-20 \mathrm{kDa}$ fraction. However, when the molecular weight of the sulfated galactans was $>20 \mathrm{kDa}$, no antibacterial activity was observed. This result is consistent with our earlier findings, in which the $\leq 6 \mathrm{kDa}$ fucoidan shows the highest antibacterial activity [6]. It is believed that sulfated polysaccharides (such as fucoidans) with low molecular weight can easily penetrate cell membranes $[19,20]$. Thus, molecular weight should be one of critical factors determining the antibacterial activity of sulfated polysaccharides. However, the cell structure of Gram-negative bacteria is different from that of animal cells. Gram-negative bacteria, such as E. coli, have an outer membrane. Therefore, whether sulfated galactans can penetrate cell membrane of $E$. coli remains to be further studied.

Sulfated polysaccharides usually exhibit polyanionic property due to their abundant contents of sulfate group and uronic acid [6]. Binding and reacting with the glycoprotein-receptors on the bacterial cell surface are suggested as the antibacterial mechanisms of polysaccharides [21]. Therefore, the charge property of sulfated galactans may affect its interaction with bacteria. According to present research, the E3 fraction with $8.0 \mathrm{mg} / \mathrm{mL}$ MIC and $12.5 \mathrm{mg} / \mathrm{mL} \mathrm{MBC} \mathrm{displayed} \mathrm{better} \mathrm{anti-ETEC} \mathrm{K88} \mathrm{activity}$ and had higher sulfate group content compared with other fractions. These results are consistent with earlier reports, in which the sulfated polysaccharides from Pleurotus eryngii with 0.69 degree of sulfonation exhibited better inhibition against E. coli and S. aureus than those from Streptococcus thermophilus ASCC 1275 with 0.31 degree of sulfonation [22]. Owing to the low uronic acid content, the sulfate group should be the main factor contributing to the polyanionic characteristics of the investigated polysaccharides. Therefore, the polyanionic property endowed by sulfate groups could be an effective modification to improve the anti-ETEC K88 activity of sulfated galactans.

In addition to molecular weight, charge density, and sulfate content, the monosaccharide unit plays an important role in the biological actions of polysaccharides [21]. In present research, no 
anti-ETEC K88 activity was observed for dextran sulfate even at $10.0 \mathrm{mg} / \mathrm{mL}$. This result is consistent with our earlier research, in which dextran sulfate even exhibited a promoting role in the proliferation of nonpathogenic E. coli [6]. According to our present results, the monosaccharide units of D-ESP are composed of $93.4 \%$ galactose, $3.2 \%$ mannose, and small amounts of xylose, glucuronic acid, and galacturonic acid. According to our earlier studies, the selected fucoidan is composed of $47.2 \%$ fuctose, $26.6 \%$ mannose, $15.0 \%$ glucose, and $11.2 \%$ galactose [6]. However, the monosaccharide composition of dextran sulfate is $100 \%$ glucose. As the pathway of bacteria invading host cells, some specific proteins (polysaccharide receptors) on the surface of microorganisms can specifically bind to the heparin sulfate on the surface of host cells [23]. Gut et al. discovered mannose-specific lectins on the fimbriae of Enterobacteria (e.g., E. coli or S. aureus) that bind to human intestinal cells [24]. The immunomodulating activity of mushroom polysaccharides containing glucose and mannose should be attributed to their binding ability with the glucose/mannose-specific receptors on human macrophages [25,26]. Therefore, the antimicrobial activity of sulfated polysaccharides might be achieved by the specific recognizing and binding of polysaccharides receptors on the bacterial surface. These actions may be regulated by the monosaccharide composition of polysaccharides. We discovered that after the administration of depolymerized sulfated galactans, the fluorescence intensity of membrane protein can be suppressed and the surfaces of ETEC K88 became deformed, pitted, and shriveled. As far as the dextran sulfate, based on above discussion, it is reasonable to believe that although dextran sulfate could bind to the polysaccharide receptor on the bacterial surface, it cannot effectively inhibit bacterial growth. This hypothesis was supported by previous studies, in which Cordyceps cicadae polysaccharide was also believed to serve as nutrition for $E$. coli growth after $24 \mathrm{~h}$ cultivation $[27,28]$. However, according to recent studies, it is reported that sulfated galactans are required for growth of Gram-positive Micrococcus luteus [29]. Therefore, the effects of sulfated polysaccharide on different microorganisms remain to be further studied.

After binding to the bacterial surface, anti-bacterial polysaccharides can further destroy the membrane structure of bacteria [30]. The increased absorbance of bacterial suspension at $260 \mathrm{~nm}$ is due to the leakage of intracellular nucleic acids; this phenomenon is a good indicator for evaluating the integrity of cell membranes [31]. In present work, significant nucleic acid release of ETEC K88 was observed after being exposed to depolymerized sulfated galactans. This result is consistent with earlier reports, in which the sulfated polysaccharides from Laminaria japonica and Sargassum polycystum also display a destructive effect on the membrane permeability for Gram-negative and -positive bacteria, including E. coli, S. aureus, and Pseudomonas aeruginosa [6,21]. However, at longer times, the amount of $260 \mathrm{~nm}$ absorbing material tended to decrease with time. This may be attributed to the adsorption of the $260 \mathrm{~nm}$ absorbing material on the precipitates during the precipitation process, which were filtered out prior to the OD measurement [32].

The interaction of specific proteins on the surface of microorganisms (adhesins) with carbohydrate chains on the glycoconjugate (receptors) of host cells enables the microbes to take their first step toward establishing an infection [24]. Therefore, inhibiting the adhesion and colonization of diarrheal pathogens on intestinal epithelium is an important therapeutic part of effectively fighting bacterial diarrhea. Gram-negative enteropathogenic bacteria including E. coli exhibit a strong binding ability to Saccharomyces cerevisiae strains [33,34]. The coagulation reaction between yeast and Gram-negative bacteria can be used as a model to simulate and study the adhesion of pathogenic bacteria to host mammalian cells [34]. Sulfated polysaccharides (e.g., heparan sulfate and chondroitin sulfate) are present on animal cells and act as the receptors of microbial adhesions [23]. Owing to their similar structure and charge property with the receptors of microbial adhesins on the host cell surface, sulfated polysaccharides may competitively bind with pathogenic bacteria and thus effectively inhibit the invasion of pathogenic bacteria on the host cells. According to our present results, the depolymerized sulfated galactans from G. verrucosa and E. serra exhibited an effectiveness in inhibiting the adhesion of diarrheogenic ETEC K88. Therefore, marine sulfated galactans have potential to replace antibiotic drugs in the treatment of bacterial diarrhea. 


\section{Materials and Methods}

\subsection{Chemicalsand Reagents}

Dextran sulfate and monosaccharide standards including xylose, mannose, galactose, glucose, glucuronic acid, and galacturonic acid were purchased from Sigma Chemical Co. (St. Louis, MO, USA). DEAE-Cellulose used for separating depolymerized sulfated polysaccharides was obtained from Sigma (Sydney, Australia). Brain heart infusion (BHI) was purchased from Shanghai Gaochuang Chemical Technology Ltd. (Shanghai, China). Deionized water was produced using a Milli-Q unit (Milipore, Bedford, MA, USA). Other analytical reagent-grade reagents were purchased from China National Pharmaceutical Industry Corporation Ltd. (Shanghai, China). The dinitrosalicylic acid (DNS) reagent was prepared according to the following steps: $10 \mathrm{~g}$ DNS and $300 \mathrm{~g}$ of sodium potassium tartrate was added to $800 \mathrm{~mL}$ of $0.5 \mathrm{~mol} / \mathrm{L} \mathrm{NaOH}$ aqueous solution and was gently heated to dissolve the reagents, and then the volume was made up to $1.0 \mathrm{~L}$ with distilled water.

\subsection{Extraction of Crude Sulfated Galactans}

The cultivated fresh E. serra (from Qingdao in China) and G. verrucosa (from Putian in China) were respectively collected in May and March 2017. The sample was washed three times with tap water to remove salt, epiphytes, and sand attached to the surface. The seaweeds were then dried, ground into powder (40 mesh sieved) and stored at $4{ }^{\circ} \mathrm{C}$ until use. The sulfated polysaccharide was isolated from E. serra according to a previous study [15], with some modifications. Briefly, $100 \mathrm{~g}$ of the dried algae powder was macerated in hot water extraction at $55^{\circ} \mathrm{C}$ for $4 \mathrm{~h}$. The E. serra syrup was then filtered through filter cloth, concentrated to $1 / 4$ th of the original volume, cooled, and precipitated with three volumes of ethanol overnight at $4{ }^{\circ} \mathrm{C}$. The precipitate was collected by centrifugation and washed 3 times with $75 \%$ ethanol, dehydrated and lyophilized to get a dried crude E. serra sulfated polysaccharide (ESP).

The extraction of the sulfated polysaccharide from the marine algae G. verrucosa was performed as described previously [35], with some modifications. Briefly, the G. verrucosa powder was extracted twice with hot water with a mass volume ratio of $1: 40(\mathrm{~g} / \mathrm{mL})$ at $55{ }^{\circ} \mathrm{C}$ for $4 \mathrm{~h}$ and filtered through the filter cloth. The combined extracts were concentrated to $1 / 4$ th of initial volume in a rotary evaporator under reduced pressure at $55^{\circ} \mathrm{C}$. Then $95 \%(\mathrm{v} / \mathrm{v})$ ethanol was added to the concentrated supernatants with constant stirring to achieve a final concentration of $40 \%$ ethanol. The solution was left at $4{ }^{\circ} \mathrm{C}$ overnight, centrifuged at $5000 \mathrm{r} / \mathrm{min}$ for $10 \mathrm{~min}$. The supernatant was added $95 \%$ ethanol again to a final concentration of $80 \%$ ethanol and kept at $4{ }^{\circ} \mathrm{C}$ overnight. The polysaccharides were collected by centrifugation as above and washed 3 times with $75 \%$ ethanol, dehydrated and lyophilized to get a dried crude G. verrucosa sulfated polysaccharide (GSP).

\subsection{Purification of Sulfated Galactans}

The crude sulfated polysaccharides were dissolved in distilled water, and the small molecules, especially for mineral substances were removed by Millipore Labscale TFF System as described in our previous studies [6]. Then, the concentrated polysaccharide solution underwent deproteinization according to the Sevag method [6]. The polysaccharide solution and the Sevag reagent (chloroform/n-butanol 4:1, v/v) were mixed (polysaccharide solution/Sevag reagent 5:1, v/v), thoroughly shaken for $30 \mathrm{~min}$, centrifuged to remove the denatured proteins, and repeated five times. After the precipitate was collected and lyophilized, the polysaccharide powder was kept in a glass desiccator at room temperature until use.

\subsection{Analysis of Chemical Composition}

Total carbohydrate content was determined by the anthrone-sulfuric acid test using galactose as the standard [36]. Sulfate content was determined by $\mathrm{BaCl}_{2}$ turbidimetric method [37]. Uronic acid content was determined by the modified sulfuric acid-carbazole method using glucuronic acid as 
standard (Sigma) [38]. The 3,6-anhydrogalactose (3,6-AG) was measured by the ester sulfate-methoxyl method using fructose as standard [39].

The monosaccharide compositions of sulfated polysaccharides were analyzed by high performance liquid charomatography (HPLC) according to a previous report [12]. Briefly, ten milligram samples were firstly hydrolyzed with $2 \mathrm{~mol} / \mathrm{L}$ trifluoroacetic acid (TFA) aqueous solution in sealed ampoule bottles at $120^{\circ} \mathrm{C}$ for $6 \mathrm{~h}$ in an oven. The hydrolyzates were removed through decompression and distillation with methanol for three times. Subsequently, the above monosaccharide mixtures and monosaccharide standers were derived into 1-phenyl-3-methyl-5-pyrazolone (PMP) methanol solution and extracted for the HPLC analysis. The samples were filtered through $0.22 \mu \mathrm{m}$ syringe filter and injected in an Agilent1100 HPLC system with an Atlantis C18 column $(4.6 \times 250 \mathrm{~mm}, 5 \mu \mathrm{m})$ and a refractive index (RI) detector. The following monosaccharide standers were used as references: xylose, mannose galactose, glucose, glucuronic acid, and galacturonic acid.

\subsection{Fourier Transform Infrared Spectroscopy (FT-IR) Analysis}

The structural characteristics of the sulfated polysaccharides were determined by FT-IR spectroscopy [15]. Briefly, $5 \mathrm{mg}$ of sample was milled in a mortar with $100 \mathrm{mg}$ of dried spectrotometer grade potassium bromide $(\mathrm{KBr})$ powder and then pressed into pellets in preparing as salt disc $(10 \mathrm{~mm} / \mathrm{dm})$ for FT-IR measurement in the frequency range of $500-4000 \mathrm{~cm}^{-1}$ at a resolution of $4 \mathrm{~cm}^{-1}$.

\subsection{Preparation of Depolymerized Sulfated Galactans and Physicochemical Property Analysis}

\subsubsection{Depolymerization and Molecular Weight Classification}

Preparation of low molecular weight polysaccharides was according to previous studies [6]. Polysaccharides containing 30\% $(\mathrm{w} / \mathrm{w})$ deionized water were degraded using an autoclave reactor (Shanghai Boxun Industry \& Commerce Co. Ltd. Medical Equipment Factory, Shanghai, China) at $121{ }^{\circ} \mathrm{C}$ and $0.103 \mathrm{MPa}$ for $40 \mathrm{~min}$. Subsequently, the depolymerized productions were dissolved in deionized water and were separated further by an ultrafiltration device (Millipore). Then, five fractions with different molecular weight regions (F1, $\leq 6 \mathrm{kDa}, \mathrm{F} 2,6-20 \mathrm{kDa} ; \mathrm{F} 3,20-50 \mathrm{kDa} ; \mathrm{F} 4,50-80 \mathrm{kDa}$; F5, $>80 \mathrm{kDa}$ ) were obtained. These fractions were lyophilized and kept in a glass desiccator at room temperature until use.

\subsubsection{Reducing Sugars and Viscosity}

The reducing sugars content was determined using the DNS assay [40]. An aliquot of each sample $(150 \mu \mathrm{L}, 1.0 \mathrm{mg} / \mathrm{mL})$ was mixed with $150 \mu \mathrm{L}$ of the DNS reagent in a test tube and the mixture was incubated in a boiling water bath for $5 \mathrm{~min}$. After cooling to room temperature, the absorbance of the supernatant was measured at $540 \mathrm{~nm}$. A calibration curve was prepared using galacturonic acid $(0-0.2 \mathrm{mg} / \mathrm{mL})$.

The viscometer of sulfated galactans depolymerized before and after was determined using a size 75 Ubbelohde semi-micro dilution type capillary viscometer (Hangzhou Zhuoxiang Technology Co. Ltd., Hangzhou, China) at $25^{\circ} \mathrm{C}$ [41]. Briefly, the viscometer and polysaccharides solutions were kept in a temperature controlled water bath at $25^{\circ} \mathrm{C}$. The concentration of polysaccharide solution was set as $5 \mathrm{mg} / \mathrm{mL}$, and the elapsed time that different samples going through the Ubbelohde viscometer was recorded. The intrinsic viscosity $[\eta]$ value was obtained by plotting $\left[\eta_{\mathrm{sv}} / C\right]$ against $C$ using the Huggins equation and the $C$ was extrapolated to zero [42].

$$
\eta_{\mathrm{sv}} / C=[\eta]+\kappa[\eta]^{2} C
$$

where $C$ is the concentration of the sample $(\mathrm{g} / \mathrm{mL}), \kappa$ is the Huggins constant, $\eta_{\mathrm{sv}}$ is the specific viscosity of the sample. 


\subsection{Fractionation by Ion-Exchange Chromatography}

The depolymerized sulfated galactans were dissolved in distilled water at $5.0 \mathrm{mg} / \mathrm{mL}$ and then fractionated using a $50 \mathrm{~cm} \times 2.6 \mathrm{~cm}$ i.d. glass column filled with DEAE-Cellulose 52 resin. After balancing by deionized water, a linear gradient of $\mathrm{NaCl}$ solution $(0$ to $0.5 \mathrm{~mol} / \mathrm{L})$ was used to elute different polysaccharide fractions at a flow rate of $1.0 \mathrm{~mL} / \mathrm{min}$. The collected fractions were determined for the carbohydrate content by anthrone-sulfuric acid method, and the fractions showing higher carbohydrate yield were pooled together. The collected fractions were lyophilized and kept in a glass desiccators at room temperature until use.

\subsection{Microbial Strains and Culture}

Standard strain of Gram-negative enterotoxigenic E. coli (ETEC K88) (CN-3-321) was purchased from Beijing Biobw Biotechnology Co., Ltd. (Biobw, Beijing, China). The bacteria were grown in Luria-Bertani (LB) medium and incubated at $37^{\circ} \mathrm{C}$ with shaking $(180 \mathrm{rpm} / \mathrm{min}$ ) for $12 \mathrm{~h}$. Cultures were harvested by centrifugation at $5000 \times g$ for $10 \mathrm{~min}$, and the pellet was washed twice and re-suspended in sterile phosphate buffer saline (PBS) to form about $10^{6}$ colony forming units (CFU) $\mathrm{mL}^{-1}$.

The wild Saccharomyces cerevisiae strain BY4741 was provided by Euroscarf (Oberursel, Germany). The yeast strains were maintained in medium containing $1 \%$ yeast extract, $2 \%$ peptone and $25 \%$ glycerol and stored at $-80^{\circ} \mathrm{C}$. For all experiments, yeast cells were grown in YPG medium (1\% yeast extract, $2 \%$ peptone, and $2 \%$ glucose) at $28^{\circ} \mathrm{C}$ for $24 \mathrm{~h}$ under constant agitation ( $\left.150 \mathrm{rpm} / \mathrm{min}\right)$. Then, the yeasts were harvested by centrifugation at $7000 \times g$ for $10 \mathrm{~min}$ and re-suspended in PBS at a concentration of $10^{8} \mathrm{CFU} / \mathrm{mL}$.

\subsection{Antibacterial Assay}

The antibacterial activity of the sulfated polysaccharides was determined using both the liquid turbidity method and plate smearing method $[43,44]$. The ETEC K88 in the logarithmic growth period was centrifuged to remove the supernatant and then diluted to a concentration of $10^{6} \mathrm{CFU} / \mathrm{mL}$ by normal saline water. In each tube, $1.6 \mathrm{~mL}$ LB medium, $2.0 \mathrm{~mL}$ polysaccharide solution, and $400 \mu \mathrm{L}$ ETEC K88 suspension were mixed. The final concentrations of polysaccharides were 2.0, 4.0, 6.0, 8.0, and $10 \mathrm{mg} / \mathrm{mL}$, respectively. After incubation at $37^{\circ} \mathrm{C}$ for $24 \mathrm{~h}$, the absorbance was read at $640 \mathrm{~nm}$ with a microplate reader (TECAN infinite 200pro, Tecan AG, Switzerland).

The susceptibility of ETEC K88 to the sulfated galactans was also validated using the plate smearing method. Firstly, the polysaccharide aqueous solutions were added into the sterilized nutrient agar before solidification, and the final concentration of polysaccharides was $7.5 \mathrm{mg} / \mathrm{mL}$. After cooling, $100 \mu \mathrm{L}$ ETEC K88 suspension $\left(10^{6} \mathrm{CFU} / \mathrm{mL}\right)$ was spread on the surface of nutrient agar containing sulfated galactans. After incubation at $37^{\circ} \mathrm{C}$ for $24 \mathrm{~h}$, the number of colonies on the plate surfaces was counted. Sterilized water was used as negative control, and kanamycin $(0.05 \mathrm{mg} / \mathrm{mL})$ was used as positive control.

\subsection{Minimal Inhibitory Concentration (MIC) and Minimal Bactericidal Concentration (MBC)}

The MIC and MBC of sulfated galactans were carried out as described by the National Committee for Clinical Laboratory Standards [45], with slight modification. The MIC was determined as the lowest concentration of polysaccharides at which no bacterial growth was detected after incubating for $24 \mathrm{~h}$, whereas the MBC was the lowest concentration of the test polysaccharides that showed no growth in

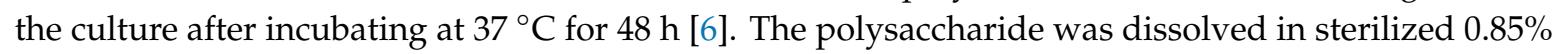
$\mathrm{NaCl}$ saline with a concentration of $50 \mathrm{mg} / \mathrm{mL}$. The serial dilutions of the polysaccharide $(25.0,12.5$, 10.0, 8.0, 6.25, 3.13, $1.56 \mathrm{mg} / \mathrm{mL}$ ) were prepared for both MIC and MBC tests. The tests were carried out in $\mathrm{LB}$ culture with an inoculum about $10^{6} \mathrm{CFU} / \mathrm{mL}$. A series of tube dilutions were incubated on a rotary shaker at $180 \mathrm{rpm} / \mathrm{min}$ for $24 \mathrm{~h}$ or $48 \mathrm{~h}$ at $37^{\circ} \mathrm{C}$. Kanamycin solution $(0.05 \mathrm{mg} / \mathrm{mL})$ was used as positive controls, and the sterilized $0.85 \% \mathrm{NaCl}$ saline was used as the negative control. 


\subsection{Integrity of Cell Membrane}

The integrity of bacterial cell membrane was examined according to the release of nucleic acid into supernatant [45]. The ETEC K88 was grown overnight at $37^{\circ} \mathrm{C}$ in $\mathrm{BHI}$, and the microorganisms were collected by centrifugation at $5000 \mathrm{rpm}$ for $15 \mathrm{~min}$. Then, bacteria were washed trice and re-suspended in $\mathrm{pH}$ 7.4 PBS. The $\mathrm{OD}_{640}$ of the suspension was adjusted to $2.0 \pm 0.02$. Subsequently, after being filtered with sterilized $0.02 \mu \mathrm{m}$ filter membranes, the bacterium removal polysaccharides with MBC concentration were added into the bacterial suspensions. Then, the bacterial suspensions were incubated at $37^{\circ} \mathrm{C}$ under agitation $(150 \mathrm{rpm} / \mathrm{min})$. The samples were centrifuged at $11,000 \mathrm{~g}$ for $5 \mathrm{~min}$ and the supernatants were measured by an ultraviolet spectrophotometer (UV-755B) at $260 \mathrm{~nm}$.

\subsection{Effect on Cell Membrane Proteins}

The binding effect of the sulfated galactans on bacterial membrane proteins was investigated by using an immunofluorescence method according to previous studies [6]. The ETEC K88 was cultured overnight at $37^{\circ} \mathrm{C}$ in BHI. Bacteria were harvested by centrifugation at $8000 \mathrm{rpm}$ for $10 \mathrm{~min}$. The precipitated cells were washed thrice and re-suspended with sterilized PBS (pH 7.4). Then, the $\mathrm{OD}_{640}$ of bacterial suspension was adjusted to $1.2 \pm 0.02$. Subsequently, after being filtered with sterilized $0.02 \mu \mathrm{m}$ filter membranes, the polysaccharides were added into the bacterial suspensions, and the final concentrations were $4.0,6.0,10.0,12.5$, and $25.0 \mathrm{mg} / \mathrm{mL}$. Then, the suspensions were incubated at $37^{\circ} \mathrm{C}$ for $5 \mathrm{~h}$, and the fluorescence level of cells was scanned ranging from $280 \mathrm{~nm}$ to $500 \mathrm{~nm}$ using a fluorescence spectrophotomemter (Cary Eclipse) at $340 \mathrm{~nm}$ excitation. The light slit width for both excitation and emission was $5 \mathrm{~nm}$.

\subsection{Inhibition of Bacterial Adhesion}

Adhesion of bacteria onto yeast cells was performed as previously described [46], with some modification. Briefly, the cultured yeast and ETEC K88 in suspensions was harvested by centrifugation at $8000 \mathrm{rpm} / \mathrm{min}$ for $10 \mathrm{~min}$, respectively. The precipitated cells were washed thrice and re-suspended with sterilized PBS (pH7.4). In the sterile centrifugal tube, $1.0 \mathrm{~mL}\left(10^{8} \mathrm{CFU} / \mathrm{mL}\right)$ yeast suspension, $0.5 \mathrm{~mL}\left(10^{9} \mathrm{CFU} / \mathrm{mL}\right)$ ETEC K88 suspension, and $0.5 \mathrm{~mL}$ PBS containing $6.0 \mathrm{mg} / \mathrm{mL}$ sulfated galactans were vortexed for $1.0 \mathrm{~min}$ and incubated at $37^{\circ} \mathrm{C}$ for $4 \mathrm{~h}$.

To morphologically observe the bacterial adhesion, scanning electron microscope (SEM) observation was performed according to a previous report [47]. The yeast-bacteria suspension was fixed overnight with $2.5 \%(\mathrm{v} / \mathrm{v})$ glutaraldehyde in PBS solution $(\mathrm{pH} 7.4)$ at room temperature. Then, the fixed bacterial pellets were submitted to dehydration with increasing ethanol concentrations (30\% to $100 \%)$, and then the ethanol was replaced with tertiary butyl alcohol. Subsequently, cells were dried after centrifugation at "critical point" in liquid $\mathrm{CO}_{2}$ under 95 bar pressure, and samples were covered in gold by cathodic spraying. Finally, the samples were observed on a SEM (PHENOMWORLD PW-100-016, Netherlands).

\subsection{Statistical Analysis}

The statistical significance of the differences between the control and treatment groups was determined by one-way ANOVA using Origin version 8.0, followed by Tukey tests. A normality test showed that all the raw data had a normal distribution, and all groups were determined to have equal variance by a variance test. Data were expressed as mean $\pm \mathrm{SD}$ of at least three individual experiments, each run in triplicate. $p<0.05$ (two-sided) was considered significant $\left({ }^{*}, p<0.05 ; * *, p<0.01\right.$ ).

\section{Conclusions}

Two kinds of sulfated galactans (ESP and GSP) were obtained from E. serra and G. verrucosa, respectively, to explore the application of sulfated polysaccharides from marine red alga in fighting against bacterial diarrhea. Their structure-activity relationship and mechanisms in inhibiting the 
growth and adhesion of diarrhea-causing ETEC K88 were also investigated. After being depolymerized, the $\leq 6 \mathrm{kDa}$ sulfated galactans exhibited the best antibacterial activity. However, no activity was observed when their molecular weight was $>20 \mathrm{kDa}$. In addition, their polyanionic property and monosaccharide composition were confirmed to influence their inhibitory activity against ETEC K88. On the aspect of antibacterial mechanism, the depolymerized sulfated galactans can bind to the membrane proteins and destroy the membrane systems of ETEC K88, ultimately leading to bacterial cell death. These depolymerized sulfated galactans can also effectively inhibit the adhesion of ETEC K88 on yeast cells, indicating their potential function in preventing the invasion of diarrheagenic bacteria on intestinal epithelium. In summary, this study emphasized the important role of depolymerized sulfated galactans from E. serra and G. verrucosa as a promising source for natural anti-diarrhea agents.

Author Contributions: Designed research, Y.L.; data curation, W.L. and Y.M.; formal analysis, Y.W.; investigation, Ling Huang; methodology, C.Z. and G.L.; project administration, Y.L.; supervision, X.Z.; writing-Original draft, D.L.; writing-Review and editing, M.-J.C.; supervision, G.-M.L. All authors read and approved the final manuscript.

Funding: This research was funded by the National Key R\&D Program of China (grant number: 2018YFD0901004) and Science and Technology Projects of Xiamen Science and Technology Bureau (grant number: 3502Z20183034).

Conflicts of Interest: The authors declare no conflict of interest.

\section{References}

1. Saeed, A.; Abd, H.; Sandstrom, G.E. Microbial aetiology of acute diarrhoea in children under five years of age in Khartoum, Sudan. J. Med. Microbiol. 2015, 64, 432-437. [CrossRef] [PubMed]

2. Levine, M.M. Escherichia coli that cause diarrhea: enterotoxigenic, enteropathogenic, enteroinvasive, enterohemorrhagic, and enteroadherent. J. Infect. Dis. 1987, 155, 377-389. [CrossRef] [PubMed]

3. Li, S.; Qi, Y.; Chen, L.; Qu, D.; Li, Z.; Gao, K.; Chen, J.; Sun, Y. Effects of Panax ginseng polysaccharides on the gut microbiota in mice with antibiotic-associated diarrhea. Int. J. Biol. Macromol. 2019, 124, 931-937. [CrossRef] [PubMed]

4. Tziveleka, L.; Ioannou, E.; Roussis, V. Ulvan, a bioactive marine sulphated polysaccharide as a key constituent of hybrid biomaterials: A review. Carbohyd. Polym. 2019, 218, 355-370. [CrossRef] [PubMed]

5. Marudhupandi, T.; Kumar, T.T.A. Antibacterial effect of fucoidan from Sargassum wightii against the chosen human bacterial pathogens. Int. Curr. Pharm. J. 2013, 2, 156-158. [CrossRef]

6. Liu, M.; Liu, Y.; Cao, M.; Liu, G.; Chen, Q.; Sun, L.; Chen, H. Antibacterial activity and mechanisms of depolymerized fucoidans isolated from Laminaria japonica. Carbohyd. Polym. 2017, 172, 294-305. [CrossRef] [PubMed]

7. Pierre, G.; Sopena, V.; Juin, C.; Mastouri, A.; Graber, M.; Maugard, T. Antibacterial activity of a sulfated galactan extracted from the marine alga chaetomorphaaerea against staphylococcus aureus. Biotechnol. Bioproc. E 2011, 16, 937-945. [CrossRef]

8. De Jesus Raposo, M.F.; de Morais, A.M.M.B.; de Morais, R.M.S.C. Influence of sulphate on the composition and antibacterial and antiviral properties of the exopolysaccharide from Porphyridium cruentum. Life Sci. 2014, 101, 56-63. [CrossRef]

9. Sousa, N.A.; Barros, F.C.N.; Araújo, T.S.L.; Costa, D.S.; Souza, L.K.M.; Sousa, F.B.M.; Leódido, A.C.M.; Pacífico, D.M.; Araújo, S.D.; Bezerra, F.F.; et al. The efficacy of a sulphated polysaccharide fraction from Hypnea musciformis against diarrhea in rodents. Int. J. Biol. Macromol. 2016, 86, 865-875. [CrossRef]

10. Bhadja, P.; Lunagariya, J.; Ouyang, J. Seaweed sulphated polysaccharide as an inhibitor of calcium oxalate renal stone formation. J. Funct. Foods 2016, 27, 685-694. [CrossRef]

11. Fan, Y.; Wang, W.; Song, W.; Chen, H.; Teng, A.; Liu, A. Partial characterization and anti-tumor activity of an acidic polysaccharide from Gracilaria verrucosa. Carbohyd. Polym. 2012, 88, 1313-1318. [CrossRef]

12. Seedevi, P.; Moovendhan, M.; Viramani, S.; Shanmugam, A. Bioactive potential and structural chracterization of sulfated polysaccharide from seaweed (Gracilaria corticata). Carbohyd. Polym. 2017, 155, 516-524. [CrossRef] [PubMed]

13. Shanmugam, M.; Mody, K.H. Heparinoid-active sulphated polysaccharides from marine algae as potential blood anticoagulant agents. J. Am. Oil Chem. Soc. 2000, 40, A6-A40. 
14. Amorim, R.D.N.D.S.; Rodrigues, J.A.G.; Holanda, M.L.; Quinderé, A.L.G.; Paula, R.C.M.D.; Melo, V.M.M.; Benevides, N.M.B. Antimicrobial effect of a crude sulfated polysaccharide from the red seaweed Gracilaria ornata. Braz. Arch. Biol. Technol. 2012, 55, 171-181. [CrossRef]

15. Kolsi, R.B.A.; Salah, H.B.; Jardak, N.; Chaaben, R.; Jribi, I.; Feki, A.E.; Rebai, T.; Jamoussi, K.; Allouche, N.; Blecker, C.; et al. Sulphated polysaccharide isolated from Sargassum vulgare: Characterization and hypolipidemic effects. Carbohyd. Polym. 2017, 170, 148-159. [CrossRef]

16. Liu, Q.; Yang, Y.; Maleki, S.J.; Alcocer, M.; Xu, S.; Shi, C.; Cao, M.; Liu, G. Anti-food allergic activity of sulfated polysaccharide from Gracilaria verrucosa is dependent on immunosuppression and inhibition of p38 MAPK. J. Agric. Food Chem. 2016, 64, 4536-4544. [CrossRef]

17. Abdelhedi, O.; Nasri, R.; Souissi, N.; Nasri, M.; Jridi, M. Sulfated polysaccharides from common smooth hound: Extraction and assessment of anti-ACE, antioxidant and antibacterial activities. Carbohyd. Polym. 2016, 152, 605-614. [CrossRef]

18. Gómez-Ordóñez, E.; Jiménez-Escrig, A.; Rupérez, P. Bioactivity of sulfated polysaccharides from the edible red seaweed Mastocarpus stellatus. Biol. Carbohyd. Diet. Fib. 2014, 3, 29-40. [CrossRef]

19. Choi, J.I.; Kim, H.J. Preparation of low molecular weight fucoidan by gamma-irradiation and its anticancer activity. Carbohyd. Polym. 2013, 97, 358-362. [CrossRef]

20. Hwang, P.A.; Hung, Y.L.; Phan, N.N.; Chang, P.M.; Li, K.L.; Lin, Y.C. The in vitro and in vivo effects of the low molecular weight fucoidan on the bone osteogenic differentiation properties. Cytotechnology 2016, 68, 1349-1359. [CrossRef]

21. Palanisamy, S.; Vinosha, M.; Rajasekar, P.; Anjali, R.; Sathiyaraj, G.; Marudhupandi, T.; Narayanasamy, S.S.; Prabhu, M.; You, S. Antibacterial efficacy of a fucoidan fraction (Fu-F2) extracted from Sargassum polycystum. Int. J. Biol. Macromol. 2019, 125, 485-495. [CrossRef] [PubMed]

22. Li, S.; Shah, N.P. Antioxidant and antibacterial activities of sulphated polysaccharides from Pleurotus eryngii and Streptococcus thermophilus ASCC 1275. Food Chem. 2014, 165, 262-270. [CrossRef] [PubMed]

23. Rostand, K.S.; Esko, J.D. Microbial adherence to and invasion through proteoglycans. Infect. Immun. 1997, 65, 1-8. [PubMed]

24. Gut, A.M.; Vasiljevic, T.; Yeager, T.; Donkor, O.N. Salmonella infection-Prevention and treatment by antibiotics and probiotic yeasts: A review. Microbiology 2018, 164, 1327-1344. [CrossRef] [PubMed]

25. Lombard, Y.; Giaimis, J.; Makaya-Kumba, M.; Fonteneau, P.; Poindron, P. A new method for studying the binding and ingestion of zymosan particles by macrophages. J. Immunol. Methods 1994, 174, 155-165. [CrossRef]

26. Ferreira, I.C.; Heleno, S.A.; Reis, F.S.; Stojkovic, D.; Queiroz, M.J.R.; Vasconcelos, M.H.; Sokovic, M. Chemical features of Ganoderma polysaccharides with antioxidant, antitumor and antimicrobial activities. Phytochemistry 2015, 114, 38-55. [CrossRef]

27. Tolstoguzov, V. Why were polysaccharides necessary? Origins Life Evol. B 2004, 34, 571-597. [CrossRef]

28. Zhang, Y.; Wu, Y.T.; Zheng, W.; Han, X.X.; Jiang, Y.H.; Hu, P.L.; Tang, Z.H.; Shi, L.E. The antibacterial activity and antibacterial mechanism of a polysaccharide from Cordyceps cicadae. J. Funct. Foods 2017, 38, $273-279$. [CrossRef]

29. Böttcher, T.; Szamosvári, D.; Clardy, J. A repeating sulfated galactan motif resuscitates dormant Micrococcus luteus bacteria. Appl. Environ. Microbiol. 2018, 84, e00745-18. [CrossRef]

30. Balamayooran, G.; Batra, S.; Fessler, M.B.; Happel, K.I.; Jeyaseelan, S. Mechanisms of neutrophil accumulation in the lungs against bacteria. Am. J. Resp. Cell Mol. 2010, 43, 5-16. [CrossRef]

31. Chen, C.Z.; Cooper, S.L. Interactions between dendrimer biocides and bacterial membranes. Biomaterials 2002, 23, 3359-3368. [CrossRef]

32. Silva, F.R.F.; Dore, C.M.P.G.; Marques, C.T.; Nascimento, M.S.; Benevides, N.M.B.; Rocha, H.A.O.; Chavante, S.F.; Leite, E.L. Anticoagulant activity, paw edema and pleurisy induced carrageenan: Action of major types of commercial carrageenans. Carbohyd. Polym. 2010, 79, 26-33. [CrossRef]

33. Gedek, B.R. Adherence of Escherichia coli serogroup O 157 and the Salmonella typhimurium mutant DT 104 to the surface of Saccharomyces boulardii. Mycoses 1999, 42, 261-264. [CrossRef]

34. Tiago, F.C.P.; Martins, F.S.; Souza, E.L.S.; Pimenta, P.F.P.; Araujo, H.R.C.; Castro, I.M.; Brandao, R.L.; Nicoli, J.R. Adhesion to the yeast cell surface as a mechanism for trapping pathogenic bacteria by Saccharomyces probiotics. J. Med. Microbiol. 2012, 61, 1194-1207. [CrossRef] [PubMed] 
35. Li, S.; Yang, X.; Ma, H.; Yan, J.; Guo, D. Purification, characterization and antitumor activity of polysaccharides extracted from Phellinus igniarius mycelia. Carbohyd. Polym. 2015, 133, 24-30. [CrossRef] [PubMed]

36. Leyva, A.; Quintana, A.; Sánchez, M.; Rodríguez, E.N.; Cremata, J.; Sánchez, J.C. Rapid and sensitive anthrone-sulfuric acid assay in microplate format to quantify carbohydrate in biopharmaceutical products: Method development and validation. Biologicals 2008, 36, 134-141. [CrossRef] [PubMed]

37. Kokoulin, M.S.; Kuzmich, A.S.; Kalinovsky, A.I.; Tomshich, S.V.; Romanenko, L.A.; Mikhailov, V.V.; Komandrova, N.A. Structure and anticancer activity of sulfated O-polysaccharide from marine bacterium Cobetia litoralis KMM 3880T. Carbohyd. Polym. 2016, 154, 55-61. [CrossRef]

38. Theander, O.; Aman, P.; Westerlund, E.; Andersson, R.; Pettersson, D. Total dietary fiber determined as neutral sugar residues, uronic acid residues, and Klason lignin (the Uppsala method): Collaborative study. J. AOAC Int. 1995, 78, 1030-1044.

39. Shi, C.; Pan, T.; Cao, M.; Liu, Q.; Zhang, L.; Liu, G. Suppression of Th2 immune responses by the sulfated polysaccharide from Porphyra haitanensis in tropomyosin-sensitized mice. Int. Immunopharmacol. 2015, 24, 211-218. [CrossRef] [PubMed]

40. Wang, J.G.; Zhang, S.Z.; Yang, B.P.; Cheng, P.; Zhuan-Di, W.U.; Jun-Yu, H.U. Application of 3,5-dinitrosalicylic acid (DNS) method to test the reducing sugar and water-soluble total sugar content in sugarcane internodes. Sugarcane Canesugar 2008, 5, 45-49.

41. Behrouzian, F.; Razavi, S.M.A.; Karazhiyan, H. Intrinsic viscosity of cress (Lepidium sativum) seed gum: Effect of salts and sugars. Food Hydrocolloid. 2014, 35, 100-105. [CrossRef]

42. Li, R.; Feke, D.L. Rheological and kinetic study of the ultrasonic degradation of xanthan gum in aqueous solutions. Food Chem. 2015, 172, 808-813. [CrossRef] [PubMed]

43. Chen, W.; Cheng, F.; Swing, C.J.; Xia, S.; Zhang, X. Modulation effect of core-wall ratio on the stability and antibacterial activity of cinnamaldehyde liposomes. Chem. Phys. Lipids 2019, 223, 104790. [CrossRef] [PubMed]

44. Lin, L.; Zhu, Y.; Li, C.; Liu, L.; Surendhiran, D.; Cui, H. Antibacterial activity of PEO nanofibers incorporating polysaccharide from dandelion and its derivative. Carbohyd. Polym. 2018, 198, 225-232. [CrossRef] [PubMed]

45. He, F.; Yang, Y.; Yang, G.; Yu, L. Studies on antibacterial activity and antibacterial mechanism of a novel polysaccharide from Streptomyces virginia H03. Food Control 2010, 21, 1257-1262. [CrossRef]

46. Gut, A.M.; Vasiljevic, T.; Yeager, T.; Donkor, O.N. Characterization of yeasts isolated from traditional kefir grains for potential probiotic properties. J. Funct. Foods 2019, 58, 56-66. [CrossRef]

47. Liu, Y.; Jiang, Y.; Zhu, J.; Huang, J.; Zhang, H. Inhibition of bacterial adhesion and biofilm formation of sulfonated chitosan against Pseudomonas aeruginosa. Carbohyd. Polym. 2019, 206, 412-419. [CrossRef] 